\title{
Penggunaan $E$-wallet dalam Membentuk Perilaku Konsumsi Mahasiswa
}

\author{
Andika Nikita Sari ${ }^{1}$, Sri Umi Mintarti ${ }^{1}$, Sugeng Hadi Utomo ${ }^{1}$ \\ ${ }^{1}$ Pendidikan Ekonomi-Universitas Negeri Malang
}

\section{INFO ARTIKEL}

\section{Riwayat Artikel:}

Diterima: 10-06-2020

Disetujui: 22-12-2020

\section{Kata kunci:}

e-wallet; consumption strategy; consumption behaviour; $e$-wallet; strategi konsumsi perilaku konsumsi

\author{
Alamat Korespondensi: \\ Andika Nikita Sari \\ Pendidikan Ekonomi \\ Universitas Negeri Malang \\ Jalan Semarang 5 Malang \\ E-mail: anindikita30@gmail.com
}

\begin{abstract}
ABSTRAK
Abstract: The reasearch is to analyze the consumption behavior of students of the Department Development Economics batch 2018 Universitas Negeri Malang who used e-wallet type linkaja and was conducted by using qualitative approach of phenomenology, since researcher analyzed deeply of the use e-wallet in shaping the consumption behavior of students. Research informants was active students majoring in Development Economics batch 2018. The results showed that, overall the use of e-wallet linkaja by students formed rational consumption behavior. The results of the study were reviewed from the intensity of e-wallet use, TAM acceptance, student consumption strategies in terms of financial management, consumption decision making and rational consumption activity of students.
\end{abstract}

\begin{abstract}
Abstrak: Tujuan penelitian ini untuk menganalisis perilaku konsumsi mahasiswa jurusan Ekonomi Pembangunan Angkatan 2018 Universitas Negeri Malang yang menggunakan $e$-wallet jenis linkaja. Penelitian ini menggunakan metode kualitatif jenis fenomenologi karena peneliti menganalisis lebih dalam fenomena penggunaan $e$-wallet dalam membentuk perilaku konsumsi mahasiswa. Informan penelitian adalah mahasiswa aktif jurusan Ekonomi Pembangunan Angkatan 2018 Universitas Negeri Malang. Hasil penelitian menunjukkan bahwa secara keseluruhan penggunaan $e$-wallet linkaja oleh mahasiswa membentuk perilaku konsumsi yang rasional. Hasil penelitian tersebut ditinjau dari intensitas penggunaan e-wallet, penerimaan TAM, strategi konsumsi mahasiswa yang ditinjau dari pengelolaan keuangan, pengambilan keputusan konsumsi mahasiswa, serta aktivitas konsumsi rasional mahasiswa.
\end{abstract}

Salah satu fenomena cashless society ditandai dengan munculnya berbagai macam $e$-wallet di Indonesia. Menurut (Singh \& Rana, 2017) dalam penelitiannya mengungkapkan fakta bahwa penggunaan pembayaran digital tertinggi berada di daerah metropolitan. Di era serba teknologi seperti saat ini, e-wallet banyak diminati oleh kalangan milenial. (Cheng, 2018) menjelaskan bahwa generasi milenial adalah kalangan mahasiswa sarjana yang mengerti teknologi serta prioritasnya, meliputi kemudahan, kecepatan, efisiensi, dan kenyamanan. Maka dapat dipastikan di zaman serba canggih ini hampir tidak ada mahasiswa yang tidak pernah menggunakan alat pembayaran online, seperti $e$-wallet dalam kegiatan berkonsumsi. E-wallet merupakan aplikasi yang digunakan sebagai alat pembayaran digital, dimana seseorang dapat menyimpan uang dan melakukan transaksi belanja online maupun offline melalui smartphone (Pachpande \& Kamble, 2018). Sementara itu, (Amoroso \& Magnier-Watanabe, 2012) mendefinisikan $e$ wallet sebagai alat transaksi non tunai tanpa menggunakan media kartu dan kegiatan transaksinya tidak secara langsung melalui pihak ketiga. Menurut (Michel, 2008) e-wallet dapat menggantikan uang cash apabila memenuhi syarat (1) harus mampu memfasilitasi transaksi tanpa membawa banyak uang tunai; (2) $e$-wallet harus mampu mempercepat pembayaran yang mana pengguna tidak perlu melakukan penghitungan; (3) $e$-wallet harus mampu mengurangi resiko serta meningkatkan keamanan dari pencuri; (4) menjaga kerahasiaan pengguna. Adapun keuntungan menggunakan $e$-wallet diungkapkan oleh (Punwatkar \& Verghese, 2018) memberikan kemudahan dan rasa aman dalam kegiatan transaksi, memberikan fleksibilitas bagi pemegang akun sehingga tidak perlu lagi pergi ke ATM dalam melakukan pembayaran, mampu meminimalisir dan menghindari bahaya jika terjadi pencurian maupun kehilangan kartu.

Kemunculan dan mudahnya penggunaan $e$-wallet sebagai alat transaksi pembayaran, tidak menutup kemungkinan akan berdampak pada perilaku konsumsi seseorang. Hal ini sejalan dengan hasil penelitian (Aydin, 2016) yang mengungkapkan bahwa kemudahan penggunaan $e$-wallet menjadi faktor yang memiliki pengaruh terhadap sikap perilaku konsumsi. Perilaku konsumsi menurut (Prasetijo, Ristiyanti dan Lhalauw, 2009) yaitu sebagai belajar mengenai dengan cara apa seseorang, kelompok, ataupun organisasi, membuat keputusan membeli suatu produk serta menggunakannya. Menurut (Pindyck \& Rubinfield, 2014) perilaku 
konsumsi adalah tindakan seseorang dalam mengalokasikan pendapatan mereka antara barang dan jasa yang berbeda-beda untuk memaksimalkan kesejahteraan konsumen tersebut. Kesejahteraan yang berbeda-beda dapat memengaruhi seseorang mengambil keputusan untuk berkonsumsi. Keputusan berkonsumsi sendiri terbagi atas konsumsi yang rasional dan irasional. Berdasarkan hal tersebut maka diketahui jika perilaku konsumen dapat mengarah kepada kegiatan konsumsi yang positif dan cenderung negatif.

Perilaku konsumen yang positif adalah kegiatan konsumsi yang masih berada pada batas wajar, artinya kegiatan konsumsi memang benar-benar untuk memenuhi kebutuhan. Sementara itu, perilaku konsumen yang cenderung negatif adalah konsumsi yang berlebihan dan membuat individu cenderung menjadi orang yang konsumtif karena melakukan kegiatan konsumsi di luar kebutuhan hidupnya. Perilaku konsumen yang positif dapat dikategorikan sebagai perilaku konsumen yang rasional sedangkan perilaku konsumen yang cenderung negatif dapat disebut sebagai perilaku konsumsi yang irasional. Hal tersebut sesuai dengan pendapat (Amalia \& Al Arif, 2013) yang menyatakan empat pilar prinsip rasionalitas konsumsi, meliputi kelengkapan (Completess), transivitas (Transitivity), kesinambungan (Continuity), dan berkonsumsi barang lebih banyak menghabiskan nilai guna barang maka lebih baik (The more is better).

Aktivitas konsumsi seseorang dapat dilihat dari pola perilaku konsumsi berdasarkan tingkat usia karena pengalaman seseorang dalam berkonsumsi tidak terlepas dari panjangnya interval waktu seseorang dalam melakukan aktivitas ekonominya termasuk dalam hal berkonsumsi menggunakan $e$-wallet. Perilaku konsumsi didasarkan pada tingkatan usia juga diperkuat dari penelitian (Wan, Zeng, \& Liang, 2013) menunjukkan bahwa pola perilaku pada pengguna dompet elektronik dibedakan berdasarkan usia dari penggunanya. Pada awalnya mereka mengetahui dompet elektronik berdasarkan pengalaman teman atau mencari sendiri informasi tersebut dari internet. Fungsi keamanan serta kemudahan menjadi salah satu pertimbangan seseorang untuk menggunakan dompet elektronik. Setelah mendapatkan manfaat maupun kepuasaan, biasanya akan mendorong seseorang untuk memberikan informasi maupun promosi kepada mereka yang belum pernah menggunakan dompet elektronik. Proses ini dapat dikatakan sebagai pembentukan kebiasaan perilaku pengguna yang mana dengan menggunakan dompet elektronik memunculkan perasaan etetis pada diri pengguna.

Penggunaan $e$-wallet yang dilakukan oleh berbagai kalangan termasuk kalangan mahasiswa, tidak terlepas dari adanya keyakinan pembelian pada konsumen. Keyakinan pembelian merupakan faktor utama yang dapat memengaruhi penggunaan pembayaran digital. Hal tersebut sejalan dengan (Wijayanthi, 2019) yang mengungkapkan bahwa faktor kepercayan dan manfaat yang dirasakan dapat memengaruhi sikap terhadap menggunakan yang kemudian mengarah pada niat perilaku untuk menggunakan e-wallet. Sependapat pula dengan (Shin, 2009) dalam penelitiannya mengemukakan bahwa selain dari rasa keamanan, pengaruh sosial dan kepercayaan seseorang dalam meggunakan $e$-wallet, TAM membangun persepsi kegunaan dan kemudahan penggunaan sehingga memiliki efek signifikan pada sikap pengguna terhadap dompet ponsel.

Berdasarkan pengamatan awal, peneliti mengamati perilaku konsumsi mahasiswa Jurusan Ekonomi Pembangunan Angkatan 2018 Universitas Negeri Malang. Beberapa mahasiswa terlihat melakukan kegiatan konsumsi, seperti membeli, memesan makanan dan jasa antar jemput pada transportasi online. Hal ini dibuktikan dengan banyaknya driver ojek online yang mengantarkan barang maupun makanan ke dalam lingkungan kampus Universitas Negeri Malang. Selain itu, peneliti melakukan dialog dengan beberapa mahasiswa mengenai konsumsi sehari-hari mereka di luar kampus, seperti membeli barang-barang pada toko online maupun merchant-merchant. Dalam melakukan kedua kegiatan konsumsi diatas diketahui pula bahwa beberapa mahasiswa menggunakan $e$-wallet jenis linkaja sebagai trend alat pembayaran digital masa kini. Kemudahan pembayaran menggunakan $e$-wallet dan promosi potongan harga yang ditawarkan tidak menutup kemungkinan akan membuat kegiatan konsumsi mahasiswa meningkat dan dampak yang ditimbulkan dapat memicu pada perubahan perilaku mahasiswa dalam berkonsumsi.

Fenomena pembayaran tanpa uang tunai seperti penggunaan $e$-wallet jenis linkaja seharusnya menjadi perhatian bagi dunia pendidikan karena pendidikan yang diterima seseorang dapat mengubah perilaku serta pengetahuan yang dimiliki oleh individu sebagai hasil dari proses mendapatkan pengetahuan, khususnya pendidikan ekonomi yang didalamnya diajarkan mengenai kegiatan ekonomi yang memberikan pembelajaran mengenai sikap seseorang dalam mengambil keputusan yang bijak dalam hal berkonsumsi sesuai kebutuhannya, mengelola uangnya dengan baik untuk membantu pengambilan keputusan seefektif dan seefisien mungkin. Sejalan dengan pemaparan diatas bahwa keputusan berkonsumsi yang dipelajari dalam pendidikan ekonomi salah satunya adalah mengenai keputusan berkonsumsi untuk membentuk perilaku konsumsi yang rasional atau irasional.

Peran pendidikan ekonomi yang telah diterima mahasiswa Jurusan Ekonomi Pembangunan Angkatan 2018 Universitas Negeri Malang memliki fungsi sebagai alat pertimbangan dalam berkonsumsi dengan menggunakan $e$-wallet jenis linkaja, sebab produk $e$-wallet jenis linkaja seringkali menyuguhkan promosi dan potongan harga yang menggiurkan konsumen untuk membeli produk barang ataupun jasa. Promosi potongan harga yang diberikan ketika melakukan pembayaran dengan linkaja memicu keinginanan emosional mahasiswa untuk membelanjakan uangnya tanpa memilah kebutuhan mana yang benar-benar harus dipenuhi. Oleh karena itu, agar mampu mencegah dan mengatasi dampak negatif dari adanya pembayaran menggunakan $e$-wallet jenis linkaja, pemahaman pendidikan ekonomi harus lebih ditingkatkan kembali agar mampu menjawab beberapa persoalan yang ditimbulkan dari penggunaan $e$-wallet jenis linkaja sebagai alat transaksi pembayaran baru. 


\section{METODE}

Penelitian ini menggunakan pendekatan kualitatif dengan jenis penelitian fenomenologi. Hal tersebut dikarenakan peneliti ingin mengetahui lebih dalam dan mengetahui fenomena di lapangan secara nyata mengenai penggunaan $e$-wallet jenis linkaja dalam membentuk perilaku konsumsi mahasiswa jurusan Ekonomi Pembangunan angkatan 2018 Fakultas Ekonomi dan Bisnis Universitas Negeri Malang. Peneliti hadir sebagai pengamat yang melakukan wawancara kepada informan dan melakukan pencatatan hasil wawancara serta observasi lapangan secara langsung. Jumlah informan yang digunakan dalam penelitian ini adalah lima orang, pemilihan informan dengan menggunakan teknik snowaball sampling. Informan penelitian yaitu mahasiswa jurusan Ekonomi Pembangunan angkatan 2018 yang berstatus masih aktif belajar di Fakultas Ekonomi dan Bisnis Universitas Negeri Malang. Mahasiswa jurusan Ekonomi Pembangunan angkatan 2018 dipilih dengan pertimbangan bahwa mahasiswa telah mendapatkan pengetahuan dasar ekonomi yang ia dapatkan melalui pembelajaran ekonomi mikro dengan materi perilaku konsumsi. Dari pengalaman pembelajaran tersebut diharapkan mahasiswa mampu menerapkan dan mempraktikkan teori ke dalam kehidupan keseharian khususnya dalam tindakan berkonsumsi. Kriteria informan yang diambil dan ditetapkan untuk diteliti adalah informan pengguna aktif dan sering melakukan transaksi pembayaran menggunakan linkaja dalam berbagai aktivitas konsumsinya serta dapat di buktikan dengan riwayat transaksi pembayaran linkajanya. Lokasi penelitian di Fakultas Ekonomi dan Bisnis Universitas Negeri Malang, bertempat di jalan Semarang No 5 Kota Malang. Teknik pengumpulan data dalam penelitian ini menggunakan teknik wawancara dan observasi, selanjutnya dianalisis dengan cara memilah data, menyusun data yang dipilih dengan menggunakan teks naratif, dan mengambil kesimpulan dari hasil analisis tersebut.

\section{HASIL}

\section{Penggunaan E-wallet untuk Berkonsumsi}

\section{Intensitas Mahasiswa dalam Menggunakan E-wallet Linkaja}

Intensitas penggunaan linkaja pada mahasiswa jurusan ekonomi pembangunan angkatan 2018 beragam. Intensitas penggunaan yang paling banyak dilakukan oleh informan ketiga, pertama, kedua dan kelima. Yang mana intensitas informan ketiga sebanyak lebih dari sepuluh kali dalam sebulan, informan satu sebanyak lima sampai sepuluh kali dalam satu bulan, informan kedua sebanyak enam sampai sembilan kali dalam satu bulan, informan kelima sebanyak lima sampai enam kali dalam sebulan. Sedangkan intensitas penggunaan linkaja informan keempat lebih sedikit jika dibandingkan dengan intensitas para informan lain, adapun intensitas informan kedua yaitu sebanyak dua sampai tiga kali dalam sebulan. Secara keseluruhan intensitas untuk aktivitas konsumsi, para informan memiliki kesamaan dalam hal pemanfaatan aplikasi tersebut untuk membeli pulsa, meskipun demikian terdapat perbedaan intensitas pada informan, yakni informan ketiga, keempat, dan kelima menggunakan linkaja untuk aktivitas pembelian kebutuhan di merchant kerjasama linkaja, seperti alfamart, tokopedia, dan MCD.

\section{Penerimaan TAM oleh Mahasiswa dalam Menggunakan E-wallet Linkaja untuk Aktivitas Konsumsi}

Penerimaan TAM (Technology Acceptance Model) pada mahasiswa jurusan ekonomi pembangunan angkatan 2018 memiliki kesamaan niat yaitu menggunakan e-wallet linkaja sebagai alat transaksi pembayaran untuk aktivitas konsumsinya. Ajakan teman sebaya, kemudahan serta manfaat yang telah dirasakan para informan ketika menggunakan e-wallet linkaja menjadikan aplikasi tersebut sebagai salah satu teknologi transaksi pembayaran yang mudah diterima oleh para informan.

\section{Strategi Konsumsi Mahasiswa Menggunakan E-wallet Linkaja di tinjau dari Pengelolaan Keuangan}

Strategi konsumsi mahasiswa pengguna $e$-wallet linkaja yang ditinjau dari pengelolaan keuangan memiliki kesamaan dalam mempertimbangkan skala prioritas sesuai kebutuhan serta mengelola keuangan dengan cara menyisihkan uang saku yang diterima dari orangtua untuk mengisi saldo linkaja dan menabung. Hal tersebut bertujuan agar para informan tetap dapat melakukan aktivitas konsumsi menggunakan linkaja dengan lancar tanpa mengganggu kegiatan menabung dan aktivitas konsumsi di luar linkaja.

\section{Perilaku Konsumsi Mahasiswa dalam Bertransaksi Menggunakan E-wallet Linkaja}

\section{Pengambilan Keputusan Konsumsi Mahasiswa dalam Menggunakan E-wallet Linkaja}

Kelima informan menyadari dan merasakan utilitas pembelian menggunakan linkaja seperti potongan harga dan cashback dirasa lebih besar keuntungannya bila dibandingkan dengan pembelian secara tunai. Hal tersebut merupakan bentuk marginalism yang dijalankan oleh para mahasiswa. Oleh karena itu, marginalis yang ditentukan oleh mahasiswa tercermin dari pengambilan keputusan konsumsi mahasiswa yang lebih memilih menggunakan linkaja sebagai alat transaksi pembayaran dalam aktivitas konsumsinya. 


\section{Aktivitas Konsumsi Rasional Mahasiswa dalam Menggunakan E-wallet Linkaja}

Aktivitas konsumsi rasional mahasiswa ketika menggunakan $e$-wallet linkaja memiliki kesamaan dalam merencanakan pembelian. Adapun cara yang dilakukan oleh para informan adalah tetap merencanakan pembelian sesuai kebutuhannya meskipun mendapat tawaran promosi harga barang dan jasa. Perencanaan pembelian yang dilakukan oleh informan ketiga memiliki keunikan sendiri, yaitu dengan mencatat setiap kebutuhan yang akan ia beli di kertas kecil, sedangkan informan pertama, kedua, keempat, dan kelima tidak memiliki catatan khusus, namun tetap dapat melakukan perencanaan pembelian.

\section{PEMBAHASAN \\ Penggunaan $E$-wallet untuk Berkonsumsi \\ Intensitas Mahasiswa dalam Menggunakan E-wallet Linkaja}

Intensitas menurut (KBBI, 2020) memiliki arti keadaan tingkatan atau ukuran intensnya. Dalam pembahasan ini, intensitas yang dimaksud adalah kecenderungan mahasiswa menggunakan linkaja sebagai alat transaksi pembayarannya. Berdasarkan hasil penelitian yang telah dilakukan pada mahasiswa jurusan Ekonomi Pembangunan angkatan 2018 Fakultas Ekonomi dan Bisnis Universitas Negeri Malang menunjukkan bahwa, intensitas mahasiswa dalam menggunakan $e$-wallet linkaja sangat beragam. Keberagaman tersebut disebabkan oleh tujuan pemenuhan kebutuhan konsumsi mahasiswa yang berbeda-beda. Adapun intensitas penggunaan $e$-wallet linkaja paling banyak dilakukan oleh informan ketiga yaitu sebanyak lebih dari sepuluh kali dalam satu bulan, informan pertama sebanyak lima sampai sepuluh kali dalam satu bulan, informan kedua sebanyak enam sampai sembilan kali dalam satu bulan, informan kelima sebanyak lima sampai enam kali dalam sebulan dan informan keempat sebanyak dua sampai tiga kali dalam sebulan. Apabila ditinjau dari intensitas untuk aktivitas konsumsi, secara keseluruhan para informan memiliki kesamaan dalam hal pemanfaatan aplikasi tersebut untuk membeli pulsa. Meskipun demikian, terdapat perbedaan intensitas pada informan yakni untuk informan ke tiga ke empat dan ke lima menggunakan linkaja untuk aktivitas pembelian kebutuhan di merchant kerjasama linkaja seperti alfamart, tokopedia dan MCD.

\section{Penerimaan TAM oleh Mahasiswa dalam Menggunakan $\boldsymbol{E}$-wallet Linkaja untuk Aktivitas Konsumsi}

Penggunaan $e$-wallet linkaja oleh mahasiswa jurusan Ekonomi Pembangunan angkatan 2018 tidak terlepas dari adanya penerimaan TAM (Technology Acceptance Model) oleh mahasiswa. Adanya penerimaan TAM tersebut tercermin dari pengakuan para mahasiswa yang telah merasakan kemudahan dan manfaat ketika menggunakan $e$-wallet linkaja, sehingga para mahasiswa berniat untuk menggunakan e-wallet linkaja sebagai alat transaksi pembayaran dalam aktivitas konsumsinya. Hal ini sejalan dengan Davis dalam (Fathi, 2014) menyatakan bahwa TAM berasal dari teori tindakan wajar yang menjelaskan sikap penggunaan dan norma subjektif memiliki pengaruh terhadap niat perilaku untuk menggunakannya. Adapun variabel utama dalam TAM yang paling memengaruhi pengguna teknologi adalah perceived usefulness dan perceived easy of use. Pengertian dari perceived usefulness mengarah pada seberapa jauh individu percaya akan penggunaan sistem yang dapat membantu kinerja mereka, sedangkan pengertian dari perceived ease of use lebih mengarah pada seberapa jauh individu percaya pada kemudahan yang dirasakan atas penggunaan sistem.

Berdasarkan hasil penelitian yang telah dilakukan pada kelima informan mahasiswa jurusan Ekonomi Pembangunan angkatan 2018 Fakultas Ekonomi dan Bisnis Universitas Negeri Malang menunjukkan bahwa secara keseluruhan penerimaan TAM pada mahasiswa memiliki kesamaan niat untuk menggunakan linkaja sebagai alat transaksi pembayarannya. Hal tersebut dapat ditinjau dari variabel utama yang dapat memengaruhi TAM yaitu perceived usefulness yang mana para mahasiswa percaya dan menggunakan $e$-wallet linkaja sebagai alat transaksi pembayaran untuk memudahkan aktivitas konsumsinya. Sedangkan ajakan teman sebaya, kemudahan serta manfaat yang telah dirasakan para mahasiwa ketika menggunakan $e$-wallet linkaja merupakan cerminan dari penerimaan mahasiswa terhadap salah satu variabel utama TAM, yaitu perceived ease of use. Kedua hal tersebut menjadikan e-wallet linkaja sebagai salah satu teknologi transaksi pembayaran yang mudah diterima oleh para mahasiswa. Hasil penelitian diatas sejalan dengan (Patel, 2018) dalam penelitiannya ia mengungkapkan bahwa faktor yang membentuk niat untuk menggunakan dompet seluler berasal dari kenyamanan dalam membeli produk online, loyalitas merek, keamanan, penawaran yang tersedia, dan kegunaan dompet digital. Senada pula dengan hasil penelitian Masinge dalam (Bagla \& Sancheti, 2018) menyatakan bahwa manfaat yang dirasakan dan kemudahan penggunaan berkorelasi positif dengan niat untuk menggunakan sistem dompet digital.

\section{Strategi Konsumsi Mahasiswa Menggunakan E-wallet Linkaja di tinjau dari Pengelolaan Keuangan}

Kegitan konsumsi yang dilakukan seseorang tentu akan berbeda dengan kegiatan konsumsi yang dilakukan oleh orang lain. Jika seseorang memahami strategi konsumsinya dengan baik dan tepat maka pengelolaan keuangannya pun akan baik pula, sehingga pemenuhan kebutuhannya akan berjalan lancar. Hal ini di karenakan strategi konsumsi dan pengelolaan keuangan memiliki hubungan yang saling memengaruhi satu sama lain. Pemenuhan kebutuhan yang dilakukan oleh mahasiwa jurusan Ekonomi Pembangunan angkatan 2018 Fakultas Ekonomi dan Bisnis Universitas Negeri Malang tidak terlepas dari adanya 
strategi-strategi dalam berkonsumsi. Adapun strategi konsumsi yang di lakukan para mahasiswa adalah dengan menyusun anggaran serta menentukan skala prioritas. Hal tersebut sejalan dengan langkah-langkah dalam menyusun anggaran yang dikemukakan oleh Nababan dan Sadalia dalam (Dwiastanti, 2015) menyatakan bahwa individu yang memiliki tanggung jawab dalam menggunakan uang akan cenderung menggunakan uang tersebut secara efektif yaitu dengan cara melakukan anggaran, menyimpan uang dan mengontrol pengeluaran, melakukan investasi, dan membayar hutang tepat waktu.

\section{Perilaku Konsumsi Mahasiswa dalam Bertransaksi Menggunakan E-wallet Linkaja Pengambilan Keputusan Konsumsi Mahasiswa dalam Menggunakan E-wallet Linkaja}

Pengambilan keputusan konsumsi mahasiswa dalam menggunakan $e$-wallet linkaja tidak terlepas dari pertimbangan marginalism yang sering dilakukan oleh mahasiswa. Marginalism adalah sebuah teori yang menggambarkan metode analisis dan nilai dalam ekonomi. Nilai tersebut ditentukan oleh berapa banyak utilitas tambahan dari layanan yang disediakan. Oleh karena itu, ketika menggunakan $e$-wallet linkaja, mahasiswa berfikir bahwa utilitas yang mereka dapatkan ketika menggunakan $e$-wallet linkaja lebih besar dibandingkan tidak menggunakan e-wallet linkaja. Hal tersebut sependapat dengan (Rianto Al Arif \& Amalia Euis, 2010) yang menyatakan bahwa kegiatan manusia yang diasumsikan sebagai homo economicus dalam menentukan pilihan sesuai dengan prinsip dan keinginannya. Setiap tindakan yang dilakukan oleh homo economicus dilandasi oleh dua hal yaitu, pertama setiap tindakan-tindakan yang dilakukan memiliki maksud untuk dapat mencapai tujuan yang berarti dalam setiap keputusan yang diambil akan mendapatkan manfaat yang tinggi (utility maximization). Sependapat pula dengan Schiffman \& Kanuk dalam (Na \& Joseph, 2014) yang menyatakan bahwa keputusan pembelian yang dilakukan oleh konsumen dapat dilihat dari perilaku respon rutinitas (routinized response behavior), yaitu kondisi konsumen yang sudah memiliki banyak pengalaman dan pengetahuan mengenai beberapa kategori merk, produk yang telah dianggap baik dan berkualitas. Dengan demikian, kegiatan pencarian informasi yang dilakukan oleh konsumen pada tingkatan ini cenderung sedikit karena konsumen sudah memahami apa yang seharusnya dipilih.

Berdasarkan hasil penelitian diketahui bahwa cara pengambilan keputusan konsumsi mahasiwa jurusan Ekonomi Pembangunan angkatan 2018 adalah dengan mempertimbangkan keuntungan yang akan dia dapatkan. Hal tersebut tercermin dari pengakuan para informan yang yakin dan lebih memilih menggunakan linkaja sebagai alat transaksi pembayaran untuk aktivitas konsumsinya, hal tersebut dikarenakan para informan telah menyadari dan merasakan utilitas pembelian menggunakan linkaja, seperti potongan harga, cashback dirasa lebih besar keuntungannya bila dibandingkan dengan pembelian secara tunai.

Keyakinan pengambilan keputusan pembelian menggunakan $e$-wallet linkaja yang dilakukan oleh mahasiswa diatas sejalan dengan teori yang dikemukakan oleh Ajzen dalam (Caesar \& Sukresna, 2017), yaitu Theory of Planned Behavior atau perilaku yang di rencanakan. Menurut Ajzen perilaku yang di rencanakan di tentukan oleh sikap terhadap perilaku, dan sikap terhadap perilaku di tentukan oleh keyakinan terhadap perilaku (behavior beliefs). Keyakinan biasanya berkaitan dengan pemahaman maupun penilaian seseorang mengenai dirinya dan lingkungan sekitarnya. Keyakinan dapat dikatakan mampu memperkuat sikap, apabila evaluasi yang dilakukan oleh seseorang dapat memperoleh informasi dan data yang menyatakan bahwa perilaku tersebut dapat memberikan keuntungan baginya. Hasil penelitian di atas sejalan pula dengan hasil penelitian yang dilakukan oleh (Yuvaraj \& Bhavani, 2018) keyakinan pembelian pada konsumen adalah faktor utama yang memengaruhi penggunaan pembayaran digital. Pembayaran digital diyakini telah mengubah kebiasaan konsumen, hal ini tercermin pada perubahan pola perilaku pembelian konsumen yang tidak terlepas dari ponsel pintar dan internet yang dipercayai pula sebagai perubahan gaya hidup konsumen.

\section{Aktivitas Konsumsi Rasional Mahasiswa dalam Menggunakan E-wallet Linkaja}

Aktivitas konsumsi rasional adalah bentuk tindakan optimal atau kegiatan konsumsi yang di lakukan oleh seseorang dengan cara memilah dan menyesuaikan kebutuhannya. Tindakan tersebut bertujuan untuk mendapatkan sesuatu sesuai dengan harapan-harapan yang di inginkan. Menurut (Putri, Widodo, \& S. Martono, 2016) secara teoritis aspek rasionalitas dapat menekan tingginya perilaku konsumsi yang berlebih. Individu yang memiliki rasionalitas tinggi dipastikan dapat memilih beberapa alternatif pilihan terhadap komoditas yang mampu memuaskan kebutuhannya. Sependapat dengan (Hidayat, 2016) menyatakan bahwa ukuran utama dari rasionalitas adalah tujuan yang dimiliki oleh seseorang. Sebuah cara dimungkinkan akan memberikan hasil yang sama maupun berbeda dengan cara lain yang telah digunakan dan cara tersebut dapat berdampak pada pemberian hasil yang lebih banyak ataupun sedikit. Apabila dalam pemilihan cara tidak tepat, maka berdampak pada pencapaian tujuan yang tidak maksimal.

Berdasarkan hasil penelitian menunjukkan bahwa aktivitas konsumsi penggunaan linkaja yang dilakukan oleh mahasiswa jurusan Ekonomi Pembangunan angkatan 2018 Universitas Negeri Malang masih tergolong rasional. Hal tersebut di karenakan kelima informan selalu merencanakan pembelian sesuai kebutuhannya, meskipun mendapat tawaran promosi harga barang dan jasa. Perencanaan pembelian yang dilakukan oleh informan ketiga memiliki keunikan sendiri yaitu dengan mencatat setiap kebutuhan yang akan ia beli di kertas kecil. Sementara itu, informan pertama, kedua, keempat, dan kelima tidak memiliki catatan khusus namun tetap dapat melakukan perencanaan pembelian. 
Aktivitas konsumsi rasional para mahasiswa diatas, sejatinya tidak terlepas dari pendidikan ekonomi formal yang telah diterima mahasiswa ketika mengikuti perkulihan. Pendidikan ekonomi tersebut memiliki andil dalam aktivitas konsumsi mahasiswa. Hal tersebut sependapat dengan (Wahyono, 2001) menyatakan bahwa makna pendidikan ekonomi dapat dilihat dari perilaku seseorang yang bertindak rasional, dimana tindakan seseorang tersebut telah direncanakan sebelumnya dan dilakukan secara sadar melalui pemikirannya yang matang. Dalam menentukan pilihan pada kegiatan ekonomi, seseorang akan mempertimbangkan efektivitas dan efisiensi. Aktivitas ekonomi individu yang rasional memiliki kemampuan dalam mengakses informasi untuk pencapaian tujuan ekonominya, mampu menyusun rencana untuk mencapai tujuan yang ditentukan dan mampu menentukan tujuan yang layak dicapai. Seseorang yang bertindak rasional memiliki dasar kuat memiliki dasar dalam menentukan pilihan baik dari akses informasi, penetapan tujuan, rencana mencapai tujuan. Pendapat ahli diatas diperkuat dengan hasil penelitian yang dilakukan oleh (Indrianawati \& Soesatyo, 2015) mengungkapkan bahwa pemahaman pendidikan ekonomi memiliki pengaruh terhadap tingkat konsumsi mahasiswa. Apabila pengetahuan pendidikan ekonomi telah diterima dan dipahami dengan baik oleh mahasiswa, maka mahasiswa tersebut akan melakukan aktivitas konsumsi yang rasional.

\section{SIMPULAN}

Penggunaan $e$-wallet linkaja yang dilakukan oleh mahasiswa jurusan Ekonomi Pembangunan angkatan 2018 membentuk perilaku konsumsi yang rasional. Perilaku konsumsi rasional mahasiswa tercermin dari aktivitas konsumsinya ketika menggunakan $e$-wallet linkaja yaitu, tetap merencanakan pembelian sesuai kebutuhannya meskipun mendapat tawaran promosi harga barang dan jasa dari linkaja. Pengambilan keputusan konsumsi yang dilakukan oleh mahasiswa adalah dengan mempertimbangkan terlebih dahulu keuntungan yang akan ia dapatkan. Hal tersebut diperkuat dengan pengakuan para mahasiswa yang lebih memilih menggunakan linkaja sebagai alat transaksi pembayaran untuk aktivitas konsumsinya, yang dikarenakan para informan telah menyadari dan merasakan utilitas pembelian menggunakan linkaja, seperti potongan harga dan cashback dirasa lebih besar keuntungannya bila dibandingkan dengan pembelian secara tunai. Selanjutnya, strategi konsumsi yang ditinjau dari pengelolaan keuangan mahasiswa adalah dengan mempertimbangkan skala prioritas sesuai kebutuhan, serta mengelola keuangan dengan cara menyisihkan uang saku yang diterima dari orangtua untuk mengisi saldo linkaja dan menabung.

Perilaku konsumsi rasional yang ditunjukkan oleh para mahasiswa ketika menggunakan -wallet linkaja sejatinya tidak terlepas dari penerimaan pendidikan ekonomi yang ia dapatkan pada mata pelajaran ekonomi mikro khususnya pada materi perilaku konsumsi, dimana para mahasiswa telah menerapkan hasil pengetahuan dengan kehidupan keseharian khususnya dalam hal berkonsumsi dan memanfaatkan teknologi pembayaran secara bijak.

Meskipun hasil penelitian menunjukkan bahwa penggunaan $e$-wallet yang dilakukan oleh mahasiswa jurusan Ekonomi Pembangunan angkatan 2018 Fakultas Ekonomi dan Bisnis Universitas Negeri Malang membentuk perilaku konsumsi yang rasional, diharapkan para mahasiswa tetap mendapatkan edukasi yang mendalam mengenai cara pengendalian pola hidup konsumtif. Dengan demikian, di zaman serba teknologi seperti saat ini, para mahasiswa dapat mengimbangi kemudahan penggunaan $e$-wallet maupun alat pembayaran baru lainnya.

Penelitian ini hanya sebatas pada bagaimana penggunaan $e$-wallet dalam membentuk perilaku konsumsi mahasiswa. Dengan demikian untuk peneliti yang mengambil bahasan yang sama kedepannya menekankan pada pengungkapkan hal-hal lebih mendalam yang berkaitan dengan informasi aktual mengenai pembentukan perilaku konsumsi mahasiswa lainnya di kota Malang, sehingga berguna untuk menambah wawasan bagi penelitian selanjutnya yang sejenis dengan penelitian ini.

\section{DAFTAR RUJUKAN}

Amalia, E., \& Al Arif, M. N. R. (2013). Kesesuaian Pembelajaran Ekonomi Islam di Perguruan Tinggi dengan Kebutuhan SDM pada Industri Keuangan Syariah di Indonesia. Inferensi, 7(1), 123. https://doi.org/10.18326/infs13.v7i1.123-142

Amoroso, D. L., \& Magnier-Watanabe, R. (2012). Building A Research Model for Mobile Wallet Consumer Adoption: The Case of Mobile Suica in Japan. Journal of Theoretical and Applied Electronic Commerce Research, 7(1), 94-110. https://doi.org/10.4067/S0718-18762012000100008

Aydin, G. (2016). Adoption of Mobile Payment Systems: A Study on Mobile Wallets. Pressacademia, 5(1), $73-73$. https://doi.org/10.17261/pressacademia.2016116555

Bagla, R. K., \& Sancheti, V. (2018). Gaps in Customer Satisfaction with Digital Wallets: Challenge for Sustainability. Journal of Management Development, 37(6), 442-451. https://doi.org/10.1108/JMD-04-2017-0144

Caesar, M. R. Al, \& Sukresna, I. M. (2017). Studi Perilaku Mahasiswa dalam Pola Pengambilan Keputusan Penggunaan Jasa Bimbingan Belajar. Diponegoro Journal of Management, 6, 1-13.

Cheng, F. M. (2018). Consumer Adoption of E-Wallets: A Study of Millennials at the Institute of Foreign Languages, Cambodia. Proceedings of the 21st Asia-Pacific Conference on Global Business, Economics, Finance \& Social Sciences, $1-16$.

Dwiastanti, A. (2015). Financial Literacy as the Foundation for Individual Financial Behavior. Journal of Education and Practice, 6(33), 99-105. 
Hidayat, R. (2016). Rasionalitas: Overview terhadap Pemikiran dalam 50 Tahun Terakhir. Buletin Psikologi, 24(2), 101-122. https://doi.org/10.22146/buletinpsikologi.26772

Indrianawati, E., \& Soesatyo, Y. (2015). Pengaruh Tingkat Pendapatan dan Pengetahuan Ekonomi terhadap Tingkat Konsumsi Mahasiswa Program Pascasarjana Universitas Negeri Surabaya. Jurnal Ekonomi Pendidikan dan Kewirausahaan, 3(1), 214-226.

Punwatkar, S., \& Verghese, M. (2018). Adaptation of e-Wallet Payment : An Empirical Study on Consumers 'Adoption Behavior in Central India 2 . International Journal of Advanced in Management, Technology and Engineering Sciences, 8(3), 1147-1156.

Na, K., \& Joseph, J. (2014). A Study on Consumer Behavior towards Fmcg Products among the Rural- Suburban Hhs of Ernakulam. Journal of Global Economics, 2(4). https://doi.org/10.4172/2375-4389.1000127

Pachpande, B. R., \& Kamble, A. A. (2018). Study of E-wallet Awareness and its Usage in Mumbai. Journal of Commerce and Management Thought, 9(1), 33. https://doi.org/10.5958/0976-478x.2018.00004.6

Patel, D. R. (2018). An Empirical Study of Mobile Wallet User Behaviour to Understand Consumer Preferences and Intention. Inspira- Journal of Modern Management \& Entrepreneurship (JMME), 8(4), 605-611.

Prasetijo, R., \& Lhalauw, J. J. O. (2009). Perilaku Konsumen. Yogyakarta: Andi.

Putri, S. F., Widodo, J., \& S. Martono. (2016). Pengaruh Literasi Keuangan melalui Rasionalitas terhadap Perilaku Konsumtif. Journal of Economic Education, 5(2), 179-192.

Rianto Al Arif, M., \& Amalia Euis. (2010). Teori Mikroekonomi: Suatu Perbandingan Ekonomi Islam dan Ekonomi Konvensional. Jakarta: Kencana.

Shin, D. H. (2009). Towards an Understanding of the Consumer Acceptance of Mobile Wallet. Computers in Human Behavior, 25(6), 1343-1354. https://doi.org/10.1016/j.chb.2009.06.001

Singh, S., \& Rana, R. (2017). Study of Consumer Perception of Digital Payment Mode. Journal of Internet Banking and Commerce,

Wahyono, H. (2001). Pengaruh Perilaku Ekonomi terhadap Intensitas Pendidikan Lingkungan Keluarga. Universitas Negeri Malang.

Wan, J., Zeng, M., \& Liang, L. (2013). Empirical Study on Usability Impact Factors of Electronic Wallet-One Card Solution within College Students. IBusiness, 05(03), 77-85. https://doi.org/10.4236/ib.2013.53010

Wijayanthi, I. M. (2019). Behavioral Intention of Young Consumers Towards E-Wallet Adoption: An Empirical Study Among Indonesian Users. Russian Journal of Agricultural and Socio-Economic Sciences, 85(1), 79-93. https://doi.org/10.18551/rjoas.2019-01.09

Yuvaraj, S., \& Bhavani, S. (2018). The Factors Influencing the Buying Behaviour of the Consumers with Digital Payment Modes. Journal of Management, 5(4), 81-96. 